\title{
Enlightenment from heavy autumn rain of West China in 2017: synergic role of atmospheric circulation at mid-high latitudes and oceanic background
}

\author{
Botao Zhou ${ }^{1,2,3,4} \cdot$ Zunya Wang $^{4}$
}

Received: 20 October 2018 / Accepted: 4 February 2019 / Published online: 7 March 2019

(C) The Author(s) 2019

\begin{abstract}
Autumn rain of West China (ARWC), a typical climate phenomenon characterized by continuous rainfall, is prone to flooding and secondary disasters. The ARWC in 2017, the greatest one since the last 30 years, resulted in an economic loss of 1.9 billion dollars and serious social impacts. It is thus urgent to understand the cause for this anomaly. In this article, the atmospheric circulations affecting the 2017's ARWC are identified. They are (1) a dipole pattern with the blocking over Europe and the trough over Lake Balkhash, which favors the southward outbreak of cold airs into West China, (2) increased water vapor transportation toward West China from the Pacific and Indian Oceans, and (3) a strengthening and northward displacement of the East Asian jet stream. The cold sea surface temperature anomaly (SSTA) in the equatorial central Pacific provides a superimposed effect. Further analysis reveals a synergic role in the interannual variability of the ARWC from the anomalies of the atmospheric circulation over Lake Balkhash and the SST in the equatorial central Pacific. The combination of anomalous trough over Lake Balkhash with cold SSTA in the equatorial central Pacific is most favorable for the increase of ARWC, while that of anomalous ridge with warm SSTA generally results in a decrease of ARWC. The combination of anomalous ridge with cold SSTA or that of anomalous trough with warm SSTA has no specific indication for ARWC anomalies.
\end{abstract}

\section{Introduction}

With the northward advance of the East Asian summer monsoon (EASM), peaks of precipitation appear successively in different regions of China. In general, the main rain belt in China during the summer season experiences three northward jumps and two stagnations along the frontier of the monsoon,

Botao Zhou

zhoubt@cma.gov.cn

1 Collaborative Innovation Center on Forecast and Evaluation of Meteorological Disasters, Nanjing University of Information Science and Technology, Nanjing, China

2 Key Laboratory of Meteorological Disaster, Ministry of Education, Nanjing University of Information Science and Technology, Nanjing, China

3 Joint International Research Laboratory of Climate and Environment Change, Nanjing University of Information Science and Technology, Nanjing, China

4 Laboratory for Climate Studies, National Climate Center, China Meteorological Administration, Beijing, China thereby forming the pre-summer rainy season in South China, the Meiyu season in the mid-lower reaches of the Yangtze River valley, and the rainy season in North China (e.g., Ding 1992; Wang and Lin 2002; Wu and Wang 2001; Chen et al. 2004; Ding and Chan 2005; Huang et al. 2012).

Another typical phenomenon related to the advance/retreat of the EASM is the so-called "autumn rain of West China" (ARWC), which features the last rainy season in China (Gao and Guo 1958; Ding 2007; Wang and Ding 2008; Yuan and Liu 2013). During September to October, cold airs become active while the warm-moist air mass has not fully withdrawn southward, causing a sub-peak of precipitation in West China. Moreover, the ratio of autumn precipitation to the annual amount and the number of rainy days across China is both the greatest in West China (Bai and Dong 2004; Ding 2007; Wang and Ding 2008).

The ARWC is mainly characterized by continuous gentle rainfall but occasionally with the occurrence of heavy rainfall or rainstorm. Less-than-normal ARWC is prone to drought, and sometimes, the drought may even extend to winter and next spring. In contrast, more-than-normal ARWC often causes waterlogging, which adversely affects agriculture and 
may also incur landslides and other disasters. Thus, it is of great importance to understand the ARWC variability and related physical mechanism in order for its prediction and for disaster prevention and mitigation. In the autumn season of 2017, continuous precipitation was observed particularly in West China. Seven provinces/municipalities (Gansu, Shaanxi, Sichuan, Chongqing, Guizhou, Hubei, and Hunan) suffered from torrential rains, floods, and geological disasters, which affected more than 6 million people, damaged 480,000 ha of crops, and induced a direct economic loss of 1.9 billion dollars. Which circulation situations are responsible for so great ARWC amount in 2017? What are differences in the physical mechanism underlying the heavy ARWC in 2017 from that of common years?

Up until now, compared with the studies on the variation of the summer precipitation in China, the researches on the ARWC topic are relatively fewer. Available studies indicated that the deep Lake Balkhash trough and Indian-Burmese trough as well as the strong western Pacific subtropical high (WPSH) are favorable for the ARWC (Bao et al. 2003; Bai and Dong 2004; Niu and Li 2008; Luo et al. 2013; Wang et al. 2015; Zhang et al. 2018). The heat source in the eastern Tibetan Plateau also plays a role (Chen et al. 2001). Nevertheless, the physical mechanism responsible for the interannual variability of ARWC is far from being clear. As for external forcing, it is well known that the El Niño events exert great impacts on the East Asian climate, through exciting anomalous anticyclone around the Philippine Sea (e.g., Zhang et al. 1999; Wang et al. 2000; Wu et al. 2017a, 2017b). The precipitation in South China tends to increase during the autumn of a developing El Niño year (Wu et al. 2003). Gu et al. (2015) further highlighted that the sea surface temperature (SST) in the tropical eastern and western Pacific contributes to the autumn precipitation in South China. Wang et al. (2015) pointed out that the tropical Northwest Pacific SST is negatively correlated with the autumn precipitation in Southwest China. The heat content of the western Pacific warm pool also has an effect, through changing the circulation pattern over the regions from the South China Sea to the IndoChina Peninsula (Zheng et al. 2018). However, the combined role of the mid-high latitude circulations and the tropical Pacific SST is still unknown.

Thus, this study is motivated to investigate the cause of the excessive ARWC in 2017 and further to explore the synergic role of the key circulation at the mid-high latitudes and the SST in the tropical Pacific in the interannual variability of ARWC. The remainder of this paper is arranged as follows. The data and methods are introduced in section 2 . The feature of the ARWC in 2017 is described in section 3, followed by an analysis on its possible cause in terms of the atmospheric circulation anomaly and the equatorial Pacific SSTA. In section 4 , we demonstrate the synergic role of the mid-high latitude atmospheric circulation and the tropical SST in the interannual variability of ARWC. The main findings are concluded in section 5 .

\section{Data and methods}

Daily gauged precipitation data of 2419 meteorological stations in China are used. Among the 2419 stations, there are 212 national reference stations, 632 national basic stations, and 1575 national meteorological observing stations. This data set was compiled by the National Meteorological Information Center of China Meteorological Administration (CMA), with quality control having been processed, including checks and corrections for climatological, station, and regional outliers and for internal, temporal, and spatial consistency (Cao et al. 2016). In the present study, the precipitation data from 1961 to 2017 at 373 national meteorological stations in West China $\left(102^{\circ}-112^{\circ} \mathrm{E} / 26^{\circ}-36^{\circ} \mathrm{N}\right.$, shown in Fig. 1) are subtracted for the analysis of the ARWC. The data of the 373 stations has high quality, with the historical records up to 30 years for a certain station and the missing records less than $20 \%$. We also use the atmospheric reanalysis data with a resolution of $2.5^{\circ} \times 2.5^{\circ}$ from the National Centers for Environmental Prediction/National Center for Atmospheric Research (NCEP/NCAR) (Kalnay et al. 1996) and the SST data with a resolution of $2^{\circ} \times 2^{\circ}$ from the National Oceanic and Atmospheric Administration (NOAA) (Smith et al. 2008). The regression and composite analyses are mainly processed in this study, with the Student $t$ test being applied to assess the statistical significance.

The beginning and the ending dates of the ARWC are identified according to the Chinese Meteorological Sector Standard-monitoring indicators for rainy season in China-the ARWC. As shown in Fig. 1, West China $\left(102^{\circ}-\right.$ $112^{\circ} \mathrm{E} / 26^{\circ}-36^{\circ} \mathrm{N}$ ) is divided into the south and north parts to identify the beginning and ending dates separately. There are 269 stations in the southern part and 104 stations in the northern part. The earlier start date in the two regions is defined as the beginning date of the ARWC, and the later withdrawal date of the two regions is defined as the ending date of the ARWC.

To be specific, three criteria are applied for the determination of the beginning (the ending) dates of the ARWC: (1) the day starting from August 21, with daily precipitation up to $0.1 \mathrm{~mm}$ occurring in at least $50 \%$ of stations in West China, is considered as one autumn rainy day; (2) if the consecutive autumn rainy days persists no less than 5 days (permission of one non-autumn rainy day during day 2 to day 4 ), this process is taken as one active autumn rainy episode. In contrast, the process with at least 5 consecutive non-autumn rainy days (permission of one autumn rainy day from day 2 to day 4 ) is regarded as one break autumn rainy episode; (3) the first (last) day of the first (last) active episode in each region is 


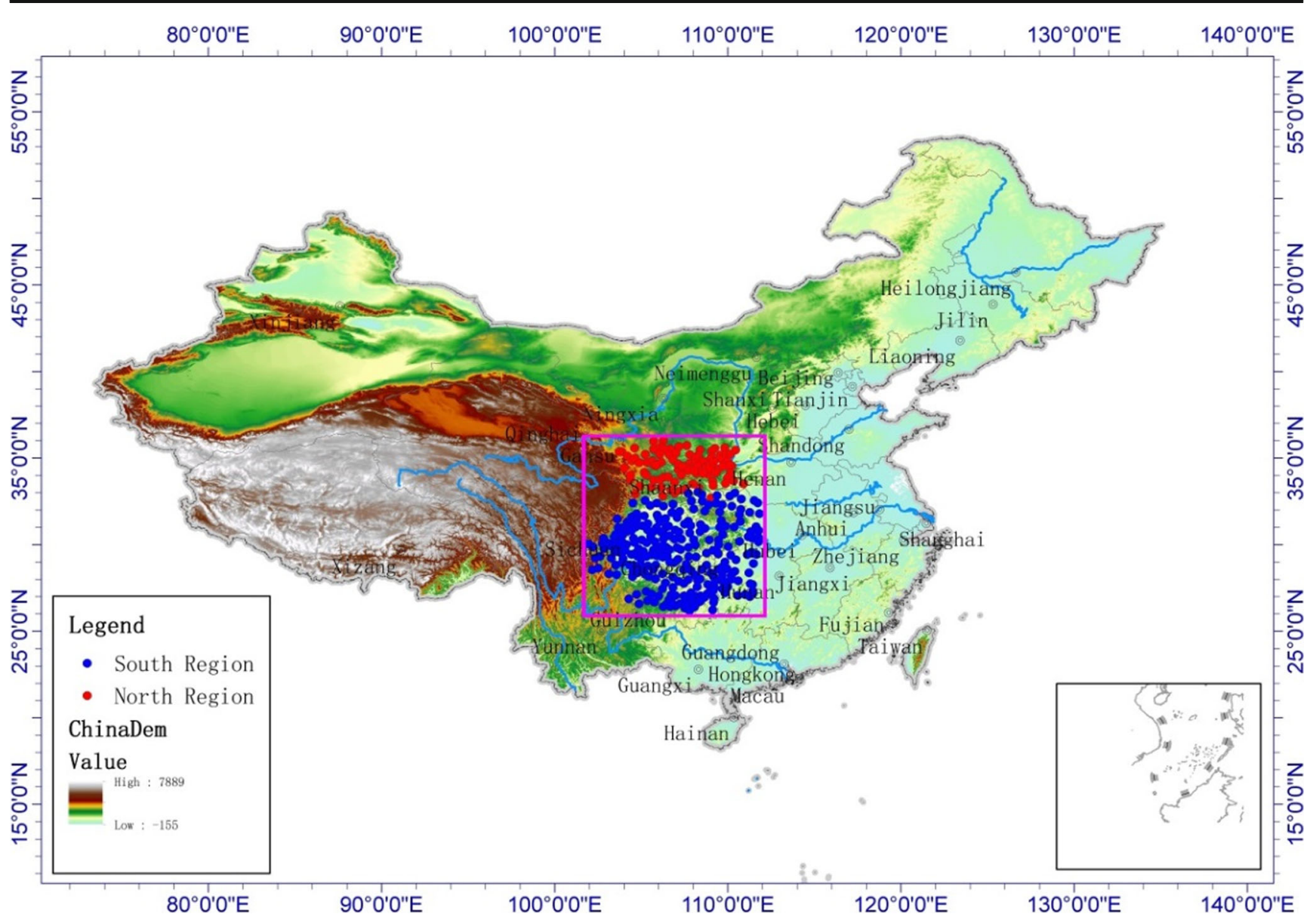

Fig. 1 Distribution of observation stations in West China $\left(102^{\circ}-112^{\circ} \mathrm{E}, 26^{\circ}-36^{\circ} \mathrm{N}\right)$ that is outlined by the pink rectangle. The red (blue) dots denote the north (south) region

determined as the start (withdrawal) date of autumn rain for this region.

\section{Characteristic of the ARWC in 2017 and related background}

Based on the aforementioned criteria, the autumn rainy period in 2017 for the north region of West China begins on August 25 and ends on October 18. Compared with their respective climatology, the beginning date appears earlier by 14 days and the ending date appears later by 5 days. For the south region, the autumn rainy period starts on August 24 (16 days earlier than the normal) and terminates on October 25 ( 5 days earlier than the normal). As a whole, for the ARWC in 2017, the beginning date is August 24 and the ending date is October 25 . They are, respectively, 7 days and 6 days earlier than the normal. The ARWC duration of 63 days in 2017, however, is close to the normal.

Fig. 2 shows the spatial distribution of the precipitation percentage anomalies over China during the ARWC period (from August 24 to October 25) in 2017. It can be clearly observed that more precipitation occurred in the extensive areas of China. For West China, the increasing amplitude is in general in the range of 20-80\%. The increase is larger in the south part than in the north part. On average, the ARWC amount in 2017 reached $301 \mathrm{~mm}, 49 \%$ higher than the normal and ranking the highest since the mid-1980s (Fig. 3).

We have examined the atmospheric and oceanic conditions related to the great ARWC amount in 2017. As displayed in Fig. 4a, at $500 \mathrm{hPa}$, a salient geopotential height anomaly pattern is observed with the blocking stretching from Europe to the polar region and the anomalous trough covering the extensive areas from Lake Balkhash to the Sea of Okhotsk. This anomalous pattern may intensify the meridional meander, favoring the southward outbreak of cold airs. During the ARWC period of 2017, there are 7 active cold air processes, which is more than the normal (5 times). Meanwhile, the WPSH is stronger than the normal and the west ridge point extends westward. Anomalies in the intensity and location of the WPSH help drive warm-moist airs northward to meet cold airs in West China.

At the lower troposphere (Fig. 4b), we can notice the prevalence of southerly anomalies over the eastern flank of West 
Fig. 2 Precipitation percentage anomalies (\%, relative to $1981-$ 2010) over China during the autumn rainy season of West China (August 24-October 25) in 2017. The pink rectangle indicates West China $\left(102^{\circ}-\right.$ $\left.112^{\circ} \mathrm{E}, 26^{\circ}-36^{\circ} \mathrm{N}\right)$

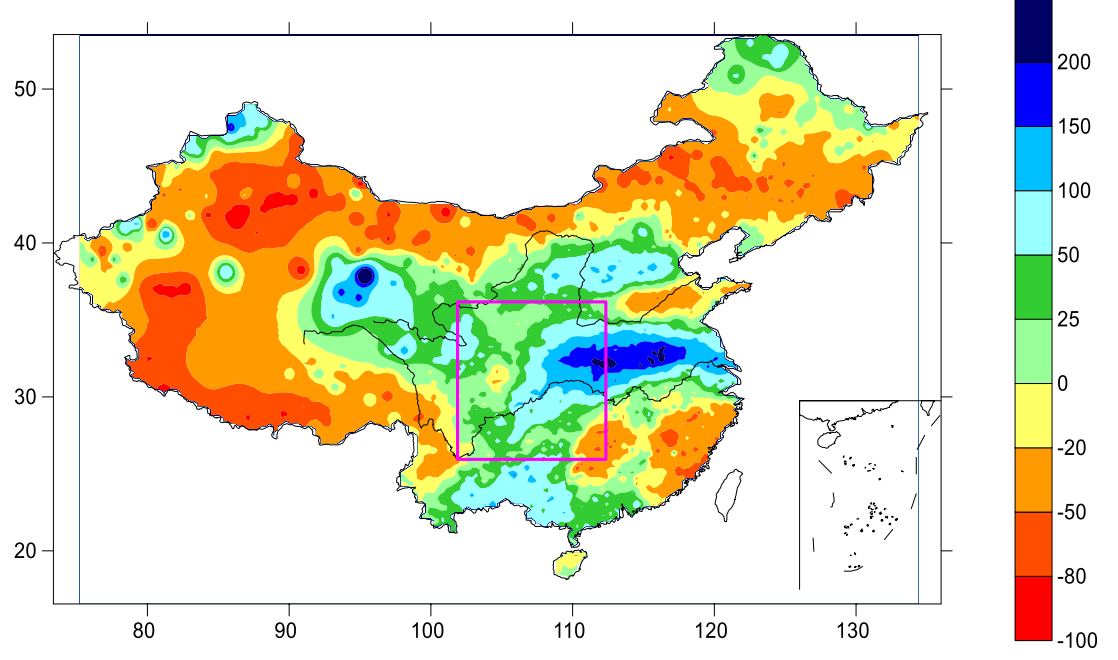

China, due to the strengthening and westward extension of the WPSH. Besides, the westerly anomalies are predominant over the tropical Indian Ocean, accompanied with anomalous cyclonic pairs residing on both sides. Such anomalies favor the transportation of warm-moist airflows from the western Pacific and Indian Oceans. This can be confirmed by the anomalies in water vapor transport flux vertically integrated from surface to $300 \mathrm{hPa}$. As shown in Fig. 5a, there are two branches of anomalous northward water vapor transport belts originating from the western Pacific and the Indian Ocean, respectively. They are converged in the region from West China to eastern China, providing more moisture for the increase of local precipitation.

At the upper troposphere (Fig. 4c), one pronounced feature is the positive (negative) anomaly of the westerly on the north (south) side of the East Asian jet (EAJ) axis, suggesting a strengthening and northward displacement of the EAJ. Due to the effect of geostrophic deviation (Ding 2005), it may induce anomalous ascending motion to the right-hand side of the entrance of the jet axis, where West China is located (Wei et al. 2018; Wang and Zhou 2019). The anomalous ascending can be further demonstrated by Fig. 5b, which plots

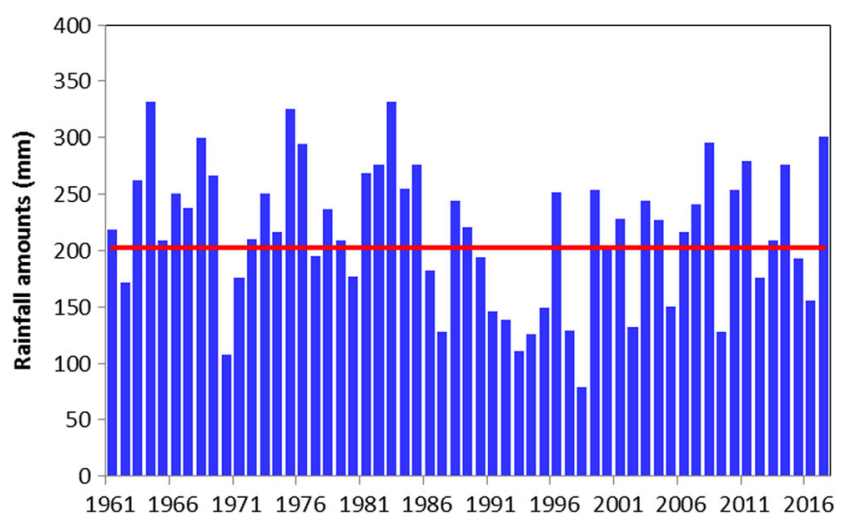

Fig. 3 Time series of the ARWC amount (mm) from 1961 to 2017 the latitude-height cross-section of the anomalies in vertical velocity along $102^{\circ}-112^{\circ} \mathrm{E}$. The negative anomalies are remarkable over the region of $20^{\circ}-35^{\circ} \mathrm{N}$, indicating an enhancement of upward motions in West China and helping to enhance local convective activities.

The tropical Pacific Ocean also exhibits significant abnormal features. Since August 2017, the SST in the central and eastern equatorial Pacific has turned from the positive anomaly to the negative anomaly. The La Niña pattern is obviously observed during September-October (Fig. 6a). Accordingly, the convections are depressed over the equatorial central Pacific while enhanced over the Maritime Continent and tropical western Pacific during the ARWC period of 2017 (Fig. 6b). As a response to the anomalous convections, a cyclonic anomaly forms over the Maritime Continent and tropical western Pacific. To its north side, according to the geostrophic balance, an anticyclonic anomaly is formed simultaneously.

In conclusion, the great ARWC amount in 2017 is the result of active interactions between the cold airs from mid-high latitudes and the warm-moist airflows from low latitudes. The frequent southward-outbreak of cold airs from high latitudes is induced by the atmospheric pattern with the blocking high over Europe and the trough over Lake Balkhash. The enhancement of the northward transport of warm-moist airflows from low latitudes is associated with the SSTA in the equatorial central and eastern Pacific.

\section{Combined effect of mid-high-latitude circulation and oceanic background on the interannual variability of ARWC}

In the previous section, we revealed the contribution from atmospheric and oceanic situations to the 2017's ARWC. We wonder whether it is the case for the ARWC in other years. 
Fig. 4 a $500 \mathrm{hPa}$ geopotential height (contours) and anomalies (shadings) (gpm), b $850 \mathrm{hPa}$ horizontal wind anomalies $(\mathrm{m} / \mathrm{s})$, and c $200 \mathrm{hPa}$ zonal wind speed (contours) and anomalies (shadings) $(\mathrm{m} / \mathrm{s})$ during the autumn rainy season of West China in 2017. The purple rectangle indicates West China $\left(102^{\circ}-112^{\circ} \mathrm{E}, 26^{\circ}-36^{\circ} \mathrm{N}\right)$
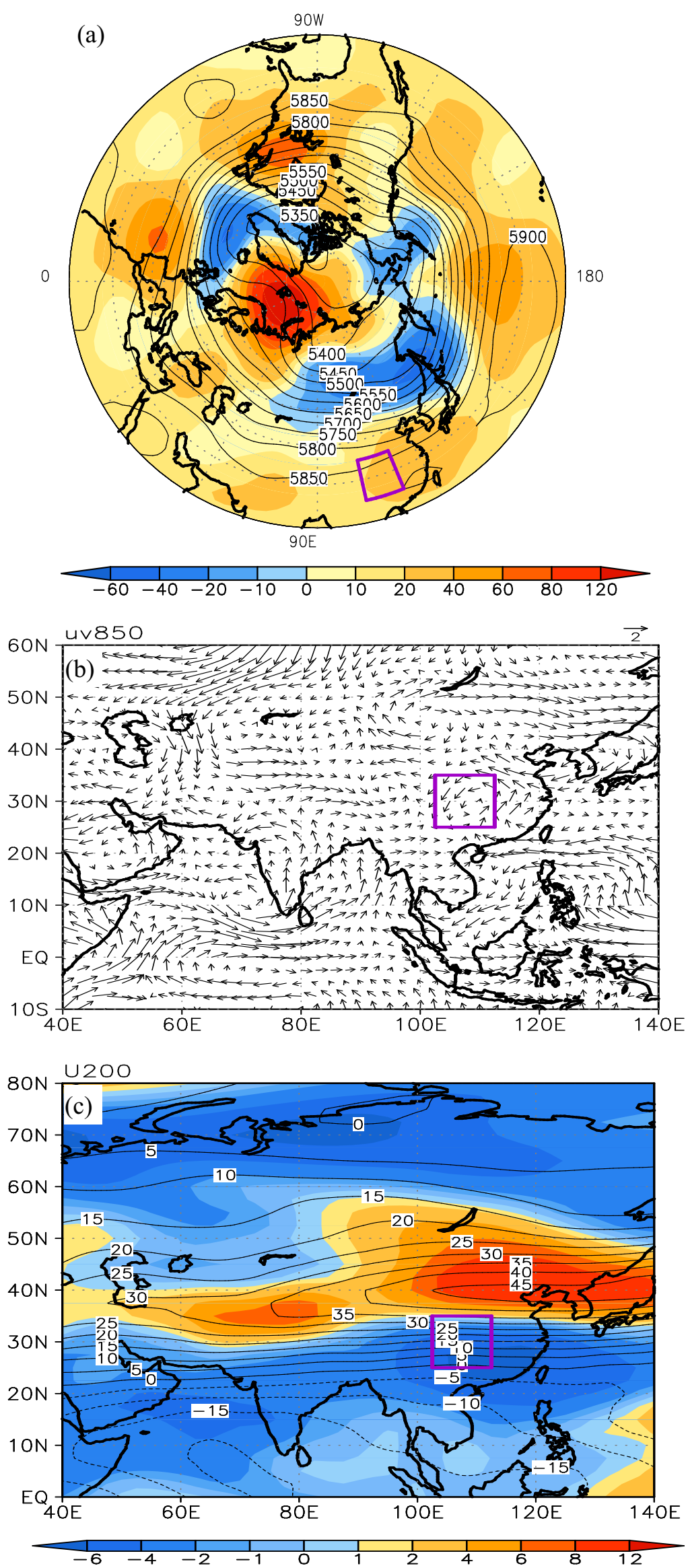
Fig. 5 a Anomalies in water vapor transport flux (vectors, $\mathrm{kg}$ $\mathrm{s}^{-1} \mathrm{~m}^{-1}$ ) and divergence (shadings, $10^{-5} \mathrm{~kg} \mathrm{~s}^{-1} \mathrm{~m}^{-2}$ ) which is vertically integrated from surface to $300 \mathrm{hPa}$, and b latitudeheight section of anomalies in vertical velocity $\left(10^{-3} \mathrm{~Pa} / \mathrm{s}\right)$ along $102^{\circ}-112^{\circ} \mathrm{E}$ during the autumn rainy season of West China in 2017. The purple rectangle indicates West China $\left(102^{\circ}-\right.$ $112^{\circ} \mathrm{E}, 26^{\circ}-36^{\circ} \mathrm{N}$ )
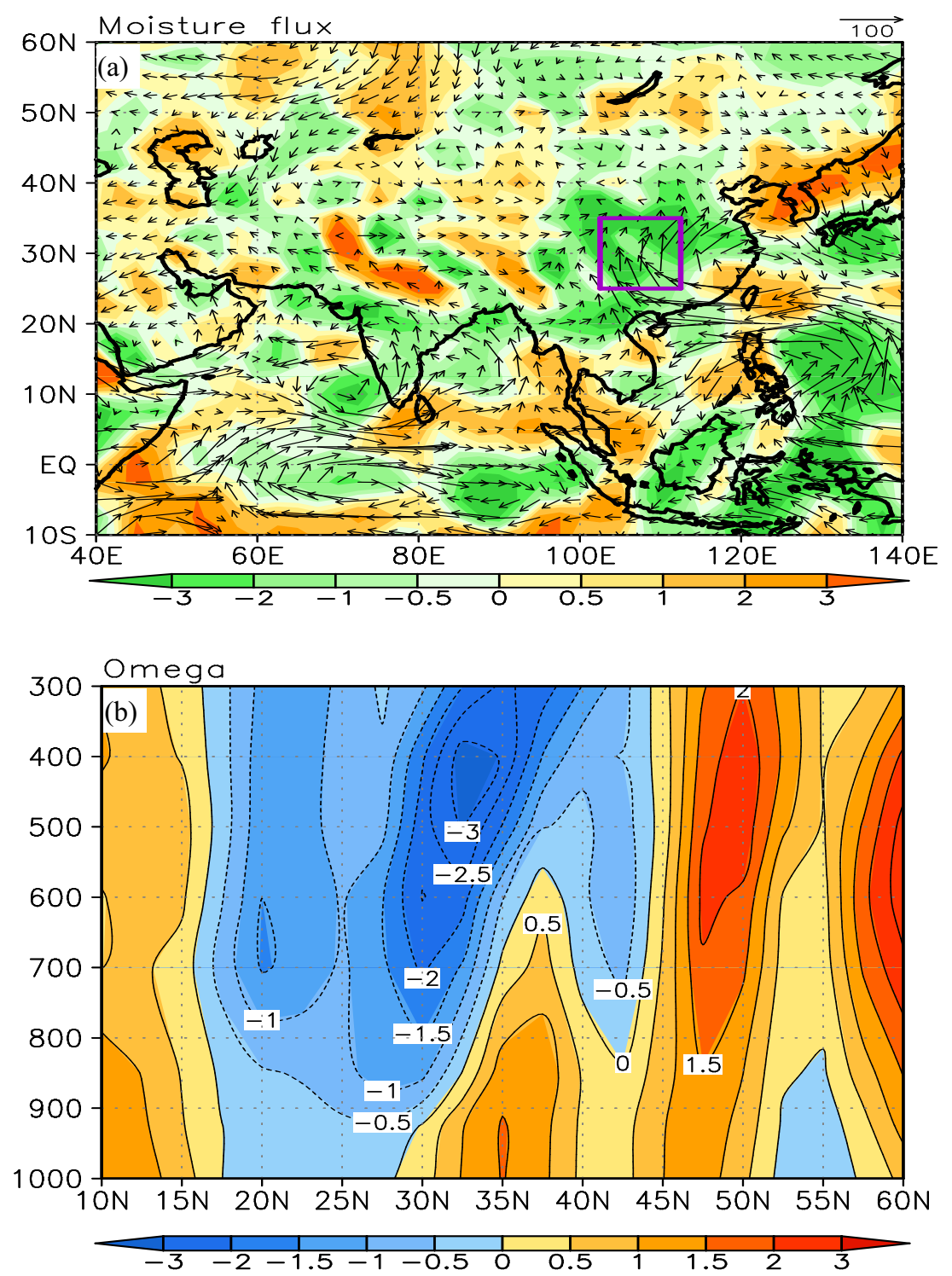

Answering this question can help us deeply understand the interannual variability of ARWC.

To identify the circulation factors affecting the interannual variability of ARWC, we plot the regressions of atmospheric circulations on the ARWC amount during 1961-2016. As shown in Fig. 7a, the "ridge-trough-ridge" pattern respectively controlling Europe, Lake Balkhash, and East Asia can be clearly observed at $500 \mathrm{hPa}$. At $850 \mathrm{hPa}$ (Fig. 7b), the easterly (westerly) anomaly prevails over the tropical western Pacific (the tropical Indian Ocean), accompanied with the anticyclonic/cyclonic (cyclonic/cyclonic) circulation on the north/south side. Especially, the southerly flow from the Indo-China Peninsula to West China is most remarkable. At $200 \mathrm{hPa}$ (Fig. 7c), the EAJ is significantly intensified and shifts northward. Through the comparison with Fig. 4, one can find that the atmospheric features associated with the interannual variability of ARWC present a general resemblance to that in 2017. Nevertheless, some differences can also be noted. For instance, for the $850 \mathrm{hPa}$ horizontal winds, the twin cyclones are located over the eastern tropical Indian Ocean, while the western Indian Ocean is dominated by the crossequatorial winds during the ARWC period of 2017, which is somewhat different from the results from the regression analysis.

Fig. 8 shows the regression pattern of the SeptemberOctober SST and convections against the ARWC amount from 1961 to 2016. A La Niña-like pattern with the cold center east to the dateline is clearly detected (Fig. 8a). That is, the cold SSTA in the equatorial central Pacific is associated with more-than-normal precipitation in West China, and vice versa. Similar to that in 2017 , the depressed convection over the central equatorial Pacific and the active convection over the Maritime Continent are significant (Fig. 8b). 
Fig. 6 Anomalies of a sea surface temperature $\left({ }^{\circ} \mathrm{C}\right)$ during September-October and $\mathbf{b}$ outgoing longwave radiation $\left(\mathrm{W} \mathrm{m}^{-2}\right.$ ) during the autumn rainy season of West China in 2017
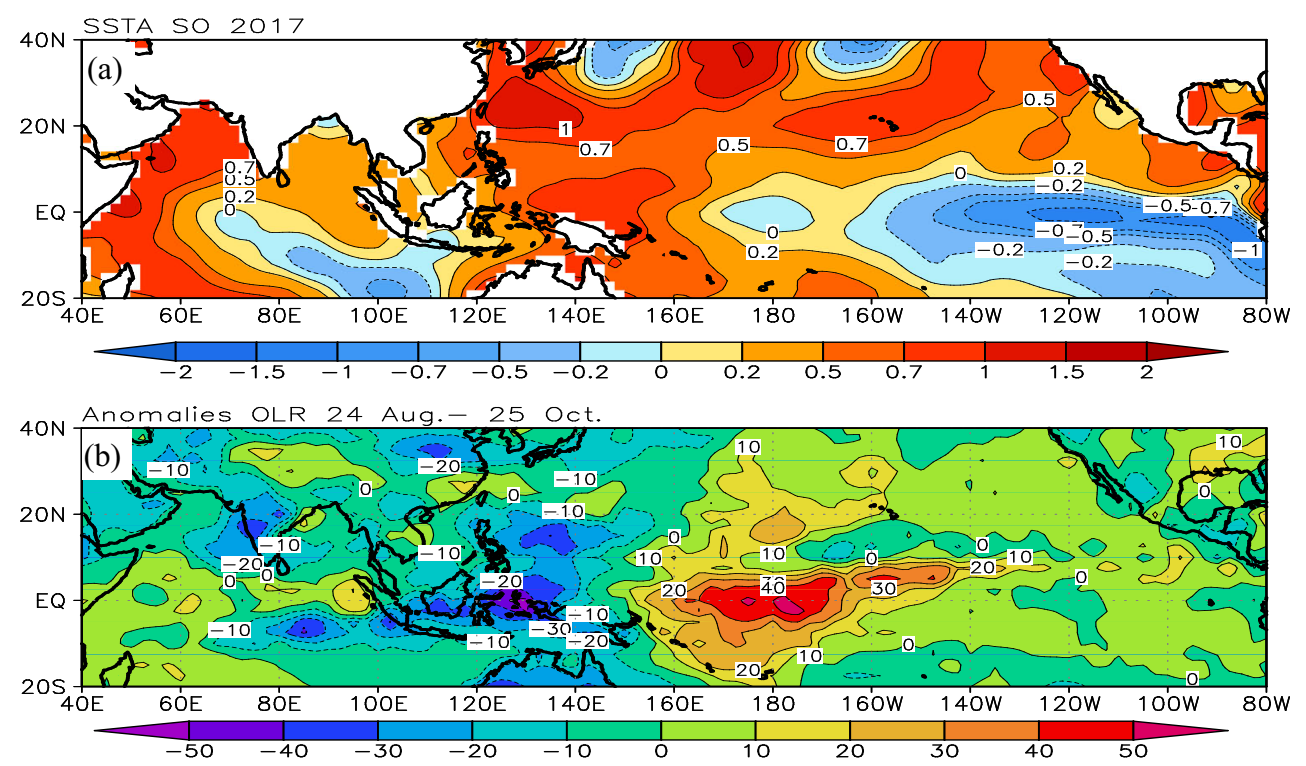

Next, we attempt to discuss the synergic effects of the key circulation over Lake Balkhash and the SST in the equatorial central Pacific on the interannual variability of ARWC. To facilitate the analysis, the normalized $500 \mathrm{hPa}$ geopotential height averaged over the region $\left(60^{\circ}-90^{\circ} \mathrm{E}, 40^{\circ}-60^{\circ} \mathrm{N}\right)$ is defined as the atmospheric index $\left(\mathrm{I}_{\mathrm{A}}\right)$ to reflect the change of the Balkhash trough. The normalized SST averaged over the region $\left(180^{\circ}-150^{\circ} \mathrm{W}, 10^{\circ} \mathrm{S}-10^{\circ} \mathrm{N}\right)$ is taken as the oceanic index $\left(\mathrm{I}_{\mathrm{O}}\right)$ to measure the $\mathrm{SST}$ variation in the equatorial central Pacific. The correlation coefficient between $\mathrm{I}_{\mathrm{A}}$ and $\mathrm{I}_{\mathrm{O}}$ is only 0.06 , almost linearly independent to each other. Thus, it is reasonable to define a synergic index $\left(\mathrm{I}_{\mathrm{S}}\right)$ by adding the oceanic index and the atmospheric index.

Fig. 9a presents the regressions of the $850 \mathrm{hPa}$ horizontal winds against the minus oceanic index $\left(-\mathrm{I}_{\mathrm{O}}\right)$. Evidently, the tropical atmosphere exhibits a significant response to cold SSTA in the equatorial central Pacific, which is featured by the prevalence of the easterly (westerly) anomaly over the tropical western Pacific (the tropical Indian Ocean) and two anomalous anticyclones (cyclones) residing on its either side. By contrast, the impact of the equatorial central Pacific SST on the atmospheric circulation over West China is rather limited. Only weak southerly anomalies are evoked. The situation, however, is different when the synergy of the SSTA in the equatorial central Pacific and the intensity of the Balkhash trough is taken into account. On the regression of the $850 \mathrm{hPa}$ horizontal wind against the minus synergic index $\left(-I_{S}\right)$ (Fig. 9b), we can notice extensive southerly anomalies over West China and its east flank, which are closely related to the increase of ARWC.

Fig. 10 further shows the September-October precipitation anomalies regressed against $-\mathrm{I}_{O}$ and $-\mathrm{I}_{S}$. As shown in Fig. 10a, the cold SSTA in the equatorial central Pacific contributes to more-than-normal precipitation along the northern West China to the mid-lower reaches of the Yangtze River valley. After adding the effect of the Balkhash trough, the statistically significant extent has broadened greatly, which covers the most region between the Yellow River valley and the Yangtze River valley (Fig. 10b).

The index correlations also support above analysis. During the period from 1961 to 2016, the correlation coefficient of the ARWC amount with the $\mathrm{I}_{\mathrm{O}}$ and the $\mathrm{I}_{\mathrm{A}}$ are -0.35 and -0.39 (both exceeding the 95\% significance level), respectively. However, its correlation with the $\mathrm{I}_{\mathrm{S}}$ increases to -0.49 , significant at the $99 \%$ level. This result suggests when the two independent factors act simultaneously, they tend to have an amplifying impact on the autumn rainfall in West China.

We further performed a statistics on the ARWC variation under different combinations of positive or negative anomalies in the oceanic and atmospheric indices. It can be found from Table 1 that the combination of cold equatorial central Pacific SSTA with deepening Lake Balkhash trough is most favorable for the increase of ARWC. Within 16 years under the control of such a situation, there are 11 years with the occurrence of more-than-normal precipitation, which accounts for $69 \%$ of the total. On the contrary, the synergy of warm SSTA in the equatorial central Pacific with ridge anomaly around Lake Balkhash is conducive to decreasing ARWC. During the last five decades, there are 13 years under the control of this background, 9 years $(69 \%)$ out of which are corresponding to less ARWC. According to the binomial test for the consistency of signs of precipitation anomalies, these anomalous changes under the two backgrounds are significant at the $95 \%$ level. The combination of cold SSTA in the equatorial central Pacific and ridge anomaly over Lake Balkhash does not show a meaningful indication for the intensifying or 
Fig. 7 Regressions of a $500 \mathrm{hPa}$ geopotential height (gpm), b $850 \mathrm{hPa}$ wind $(\mathrm{m} / \mathrm{s})$, and $\mathbf{c}$ $200 \mathrm{hPa}$ zonal wind $(\mathrm{m} / \mathrm{s})$ during September to October against the ARWC amount from 1961 to 2016. The red frame in (a) indicates the key area $\left(60^{\circ}-90^{\circ} \mathrm{E}\right.$, $40^{\circ}-60^{\circ} \mathrm{N}$ ) used for the definition of the atmospheric index. Purple dots in (a) and (c) as well as the shadings in (b) indicate the regions above the $95 \%$ significance level. The purple rectangle indicates West China $\left(102^{\circ}-112^{\circ} \mathrm{E}, 26^{\circ}-36^{\circ} \mathrm{N}\right)$
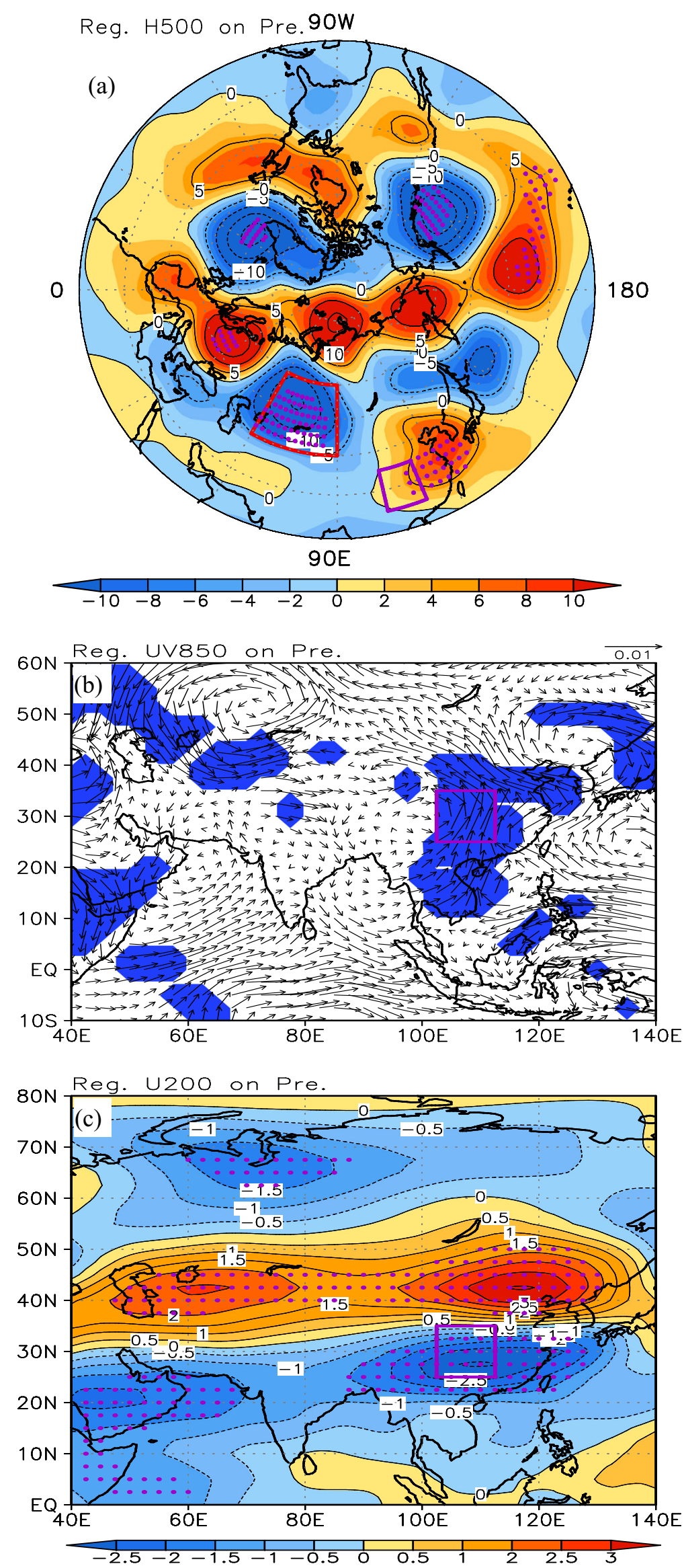
Fig. 8 Regressions of a sea surface temperature $\left({ }^{\circ} \mathrm{C}\right)$ and $\mathbf{b}$ outgoing longwave radiation $\left(\mathrm{W} \mathrm{m}^{-2}\right.$ ) during SeptemberOctober against the ARWC amount from 1961 to 2016. The red frame in (a) indicates the key area $\left(180^{\circ}-150^{\circ} \mathrm{W}, 10^{\circ} \mathrm{S}-10^{\circ} \mathrm{N}\right)$ used for the definition of the oceanic index. Regions above the 95\% significance level are shaded
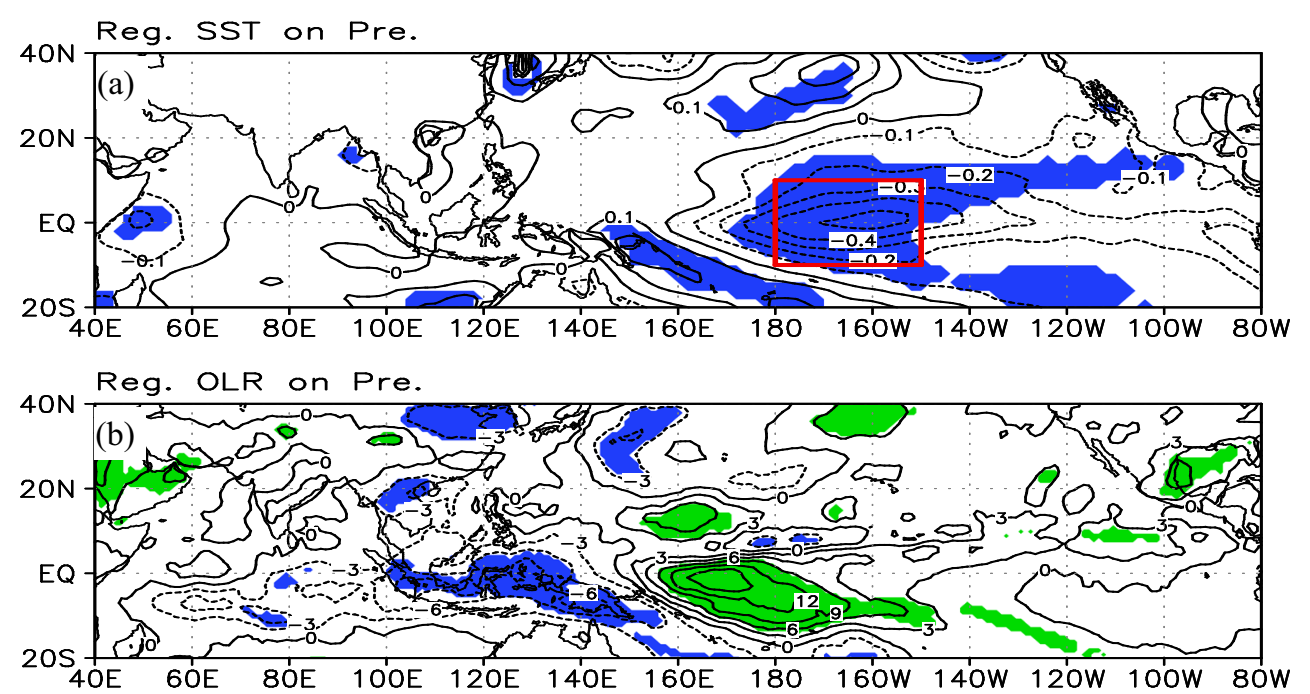

weakening of ARWC. The probability of the positive and negative signs of precipitation anomalies is about half to half under this background. The case is similar for the combination of warm equatorial central Pacific SSTA and deep Lake Balkhash trough. The multivariate linear regression between the ARWC and the atmospheric and oceanic indices is also calculated. The correlation of the regressed ARWC with the observation reaches 0.49 (significant at the $99 \%$ level). About $68 \%$ of the years show the consistent anomalies between the regressed and the observed ARWC.

\section{Summary}

In 2017, the ARWC amount is significantly more than the normal, recording the greatest one since the mid-1980s. Starting by analyzing its cause, this paper reveals the factors affecting the interannual variation of ARWC, and the synergic effect from the atmospheric circulation in the mid-high latitudes and the oceanic SST in the tropic Pacific.

The large-scale atmospheric situations associated with the increase of ARWC include the dipole pattern with the
Fig. 9 Regressions of $850 \mathrm{hPa}$ horizontal wind $(\mathrm{m} / \mathrm{s})$ against a the oceanic index and $\mathbf{b}$ the synergic index during

September-October from 1961 to 2016. The indices are multiplied by -1 . Regions above the $95 \%$ significance level are shaded. The black rectangle indicates West China $\left(102^{\circ}-112^{\circ} \mathrm{E}, 26^{\circ}-36^{\circ} \mathrm{N}\right)$
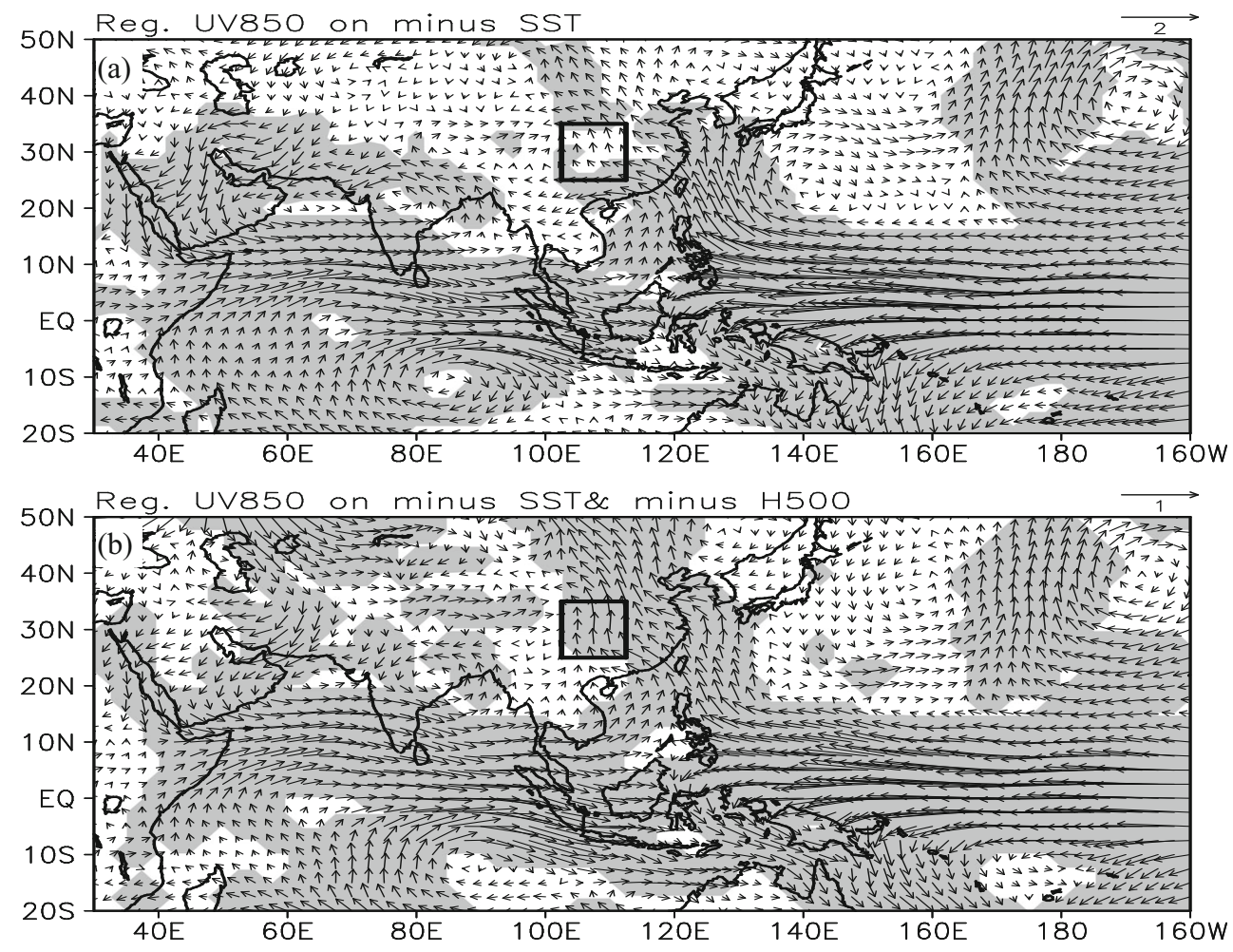
Fig. 10 Regressions of precipitation against $\mathbf{a}$ the oceanic index and $\mathbf{b}$ the synergic index during September-October from 1961 to 2016 . The indices are multiplied by -1 . The black crosses denote the stations above the $95 \%$ significance level. The pink rectangle indicates West China $\left(102^{\circ}-112^{\circ} \mathrm{E}, 26^{\circ}-36^{\circ} \mathrm{N}\right)$
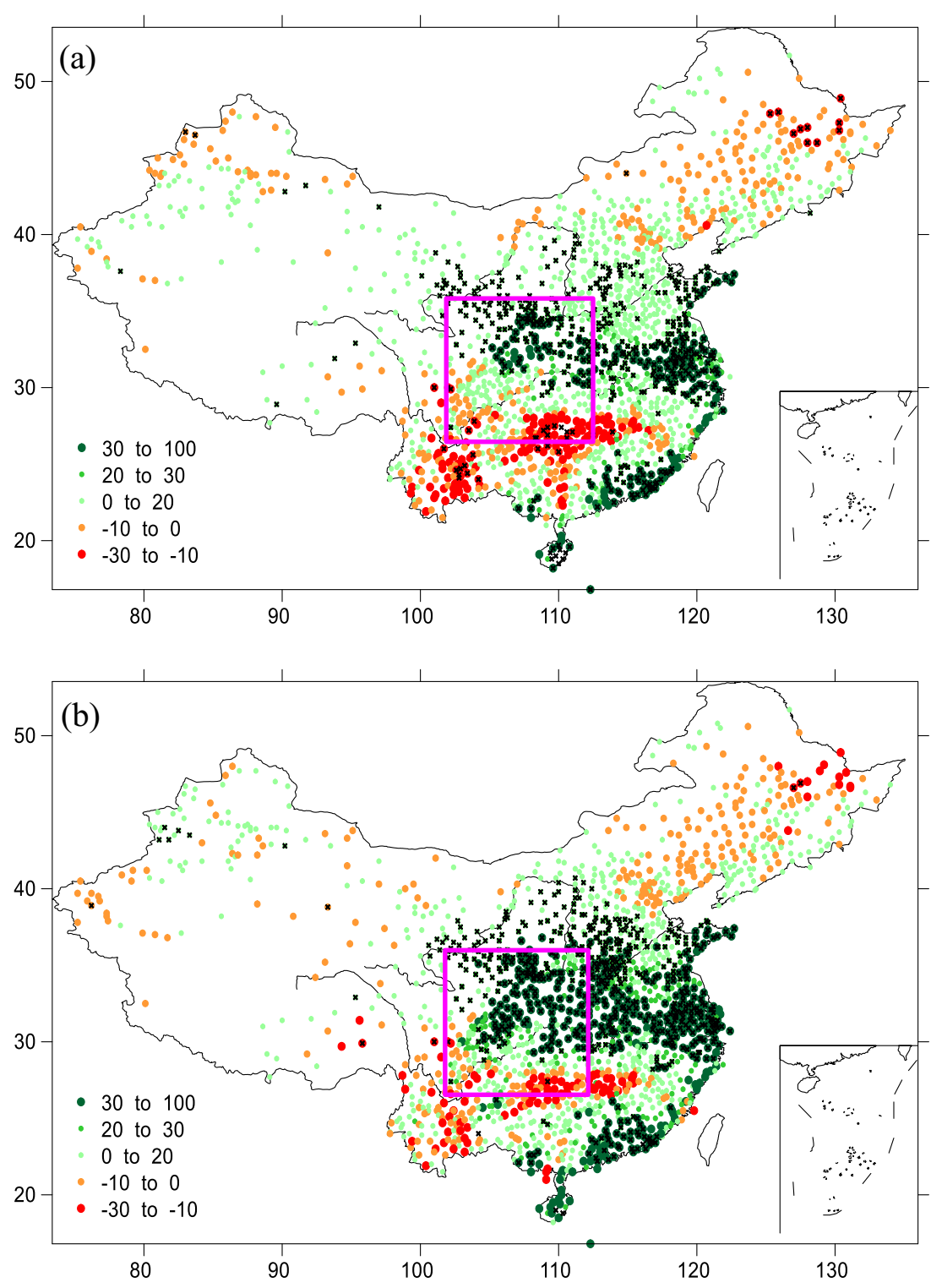

blocking over Europe and the trough over Lake Balkhash, the southerly anomalies prevailing in West China to eastern China, and the strengthening and northward displacement of the EAJ. The dipole pattern, due to its great meridional meander, is favorable for the southward outbreak of cold airs into West China. The prevalent southerly anomalies are conducive

Table 1 Statistical results for the number of years and the corresponding percentages (shown in parentheses) with positive or negative ARWC anomalies under different combinations of atmospheric index $\left(\mathrm{I}_{\mathrm{A}}\right)$ and oceanic index $\left(\mathrm{I}_{\mathrm{O}}\right)$ during September-October

\begin{tabular}{|c|c|c|c|c|}
\hline & $-\mathrm{I}_{\mathrm{A}}$ and $-\mathrm{I}_{\mathrm{O}}$ & $+\mathrm{I}_{\mathrm{A}}$ and $-\mathrm{I}_{\mathrm{O}}$ & $-\mathrm{I}_{\mathrm{A}}$ and $+\mathrm{I}_{\mathrm{O}}$ & $+\mathrm{I}_{\mathrm{A}}$ and $+\mathrm{I}_{\mathrm{O}}$ \\
\hline Years & $\begin{array}{c}1961,1962,1964,1973, \\
1975,1983,1984, \\
1985,1989,1995, \\
1996,2000,2008, \\
2013,2016,2017\end{array}$ & $\begin{array}{c}1970,1971,1974, \\
1978,1981,1988, \\
1998,1999,2005, \\
2007,2010,2011\end{array}$ & $\begin{array}{c}1963,1965,1968,1969, \\
1972,1976,1987,1990 \\
1992,1993,2001,2004, \\
2006,2012,2014,2015\end{array}$ & $\begin{array}{l}1966,1967,1977, \\
1979,1980,1982, \\
1986,1991,1994, \\
1997,2002,2003, \\
2009\end{array}$ \\
\hline $\begin{array}{l}\text { Number of years with } \\
\text { positive ARWC anomaly }\end{array}$ & $11(69 \%)$ & $7(58 \%)$ & $8(50 \%)$ & $4(31 \%)$ \\
\hline $\begin{array}{l}\text { Number of years with } \\
\text { negative ARWC anomaly }\end{array}$ & $5(31 \%)$ & $5(42 \%)$ & $8(50 \%)$ & $9(69 \%)$ \\
\hline Significance level & $95 \%$ & / & / & $95 \%$ \\
\hline
\end{tabular}


to the transportation of water vapor from the Pacific and Indian Oceans to West China. The strengthening and northward displacement of the EAJ may provide a favorable dynamic uplifting condition.

Further analyses indicate that the equatorial central Pacific SST and the Lake Balkhash trough, two factors independent to each other, have remarkable synergic effects on the variation of ARWC. The combination of cold equatorial central Pacific SSTA with deepening Lake Balkhash trough is most favorable for the increase of ARWC, while the case is generally reversed for the warm SSTA background concurrent with the weakening Lake Balkhash trough. Neither the combination of cold SSTA in the equatorial central Pacific and ridge anomaly around Lake Balkhash nor that of warm SSTA and trough anomaly has a specific indication for the ARWC anomalies. This finding provides a clue to understand the interannual variability of ARWC. Actually, the tropical-extratropical configuration is also valid for the summer rainfall over East Asia (Wang and $\mathrm{Gu}$ 2016).

Although this study highlights the synergic role from the equatorial central Pacific SST and the Lake Balkhash trough, other processes may exert important impacts on the ARWC anomalies particularly for a specific year. Besides, we note that there is also excessive rainfall in the mid-lower reaches of the Yangtze River valley during the ARWC period in 2017 (Fig. 2). As presented in Fig. 10, both the cold equatorial central Pacific SSTA and its combination with the deep Balkhash trough may have contribution. However, the detailed physical mechanism for the autumn rainfall in the Yangtze River valley, which is beyond the scope of this study, needs further in-depth investigation.

Funding information This research was jointly supported by the National Natural Science Foundation of China (41675069), the National Key Research and Development Program of China (2016YFA0600701), the Startup Foundation for Introducing Talent of NUIST, and the National Program for Support of Top-notch Young Professionals.

Open Access This article is distributed under the terms of the Creative Commons Attribution 4.0 International License (http:// creativecommons.org/licenses/by/4.0/), which permits unrestricted use, distribution, and reproduction in any medium, provided you give appropriate credit to the original author(s) and the source, provide a link to the Creative Commons license, and indicate if changes were made.

Publisher's note Springer Nature remains neutral with regard to jurisdictional claims in published maps and institutional affiliations.

\section{References}

Bai H, Dong W (2004) Climate features and formation causes of autumn rain over southwest China. Plateau Meteorol 23(6):884-889
Bao Y, Ablmit LF, Wang X (2003) Space-time distribution and physical mechanisms of autumn rains in west China in 2001. J Appl Meteor Sci 14:215-222

Cao L, Zhu Y, Tang G, Yuan F, Yang Z (2016) Climatic warming in China according to a homogenized data set from 2419 stations. Int $\mathbf{J}$ Climatol 36:4384-4392

Chen Z, Liu F, Zhao P (2001) Relationship between the surface heating fields over Qinghai-Tibet plateau and precipitation of southwest China in autumn. Plateau Meteorol 20(1):94-99

Chen TC, Wang SY, Huang WR, Yen MC (2004) Variation of the East Asian summer monsoon rainfall. J Clim 17:2271-2290

Ding Y (1992) Summer monsoon rainfalls in China. J Meteor Soc Jpn 70: 373-396

Ding Y (2005) Advanced synoptic meteorology (in Chinese). China Meteorological Press, Beijing, pp 138-149

Ding Y (2007) The variability of the Asian summer monsoon. J Meteorol Soc Jpn 85:21-54

Ding Y, Chan CL (2005) The East Asian summer monsoon: an overview. Meteor Atmos Phys 89:117-142

Gao Y, Guo Q (1958) On the autumn raining area in China. Acta Meteor Sin 29(4):264-273

Gu W, Wang L, Li W, Chen L, Sun C (2015) Influence of the tropical Pacific east-west thermal contrast on the autumn precipitation in South China. Int J Climatol 35:1543-1555. https://doi.org/10. 1002/joc. 4075

Huang R, Chen J, Wang L, Lin Z (2012) Characteristics, processes, and causes of the spatio-temporal variabilities of the East Asian monsoon system. Adv Atmos Sci 29(5):910-942

Kalnay E, Kanamitsu M, Kistler R, Collins W, Deaven D, Gandin L, Iredell M, Saha S, White G, Woollen J, Zhu Y, Leetmaa A, Reynolds R, Chelliah M, Ebisuzaki W, Higgins W, Janowiak J, Mo KC, Ropelewski C, Wang J, Jenne R, Joseph D (1996) The NCEP/NCAR 40-year reanalysis project. Bull Am Meteorol Soc 77(3):437-471

Luo X, Li D, Wang H (2013) New evolution features of ARWC and its responses to atmospheric circulation. Plateau Meteorol 32(4):10191031

Niu N, Li J (2008) Interannual variability of autumn precipitation over south China and its relation to atmospheric circulation and SST anomalies. Adv Atmos Sci 25(1):117-125

Smith TM, Reynolds RW, Peterson TC, Lawrimore J (2008) Improvements NOAAs historical merged land-ocean temp analysis (1880-2006). J Clim 21:2283-2296

Wang Z, Ding Y (2008) Climatic characteristics of rainy seasons in China. Chinese J Atmos Sci 32(1):1-13

Wang L, Gu W (2016) The eastern China flood of June 2015 and its causes. Sci Bull 61(2):178-184

Wang B, Lin H (2002) Rainy season of the Asian-Pacific summer monsoon. J Clim 15:386-396

Wang Z, Zhou B (2019) Observed decadal transition in trend of autumn rainfall over central China in the late 1990s. J Clim 32:1395-1409. https://doi.org/10.1175/JCLI-D-18-0112.1

Wang B, Wu R, Fu X (2000) Pacific-East Asian teleconnection: how does ENSO affect East Asian climate? J Clim 13:1517-1536

Wang L, Chen W, Zhou W, Huang G (2015) Teleconnected influence of tropical Northwest Pacific sea surface temperature on interannual variability of autumn precipitation in Southwest China. Clim Dyn 45:2527-2539

Wei T, He S, Yan Q, Dong W, Wen X (2018) Decadal shift in West China autumn precipitation and its association with sea surface temperature. J Geophys Res 123:835-847

Wu R, Wang B (2001) Multi-stage onset of the summer monsoon over the Western North Pacific. Clim Dyn 17:277-289

Wu R, Hu Z, Kirtman BP (2003) Evolution of ENSO-related rainfall anomalies in East Asia. J Clim 16:3742-3758 
Wu B, Zhou T, Li T (2017a) Atmospheric dynamic and thermodynamic processes driving the western North Pacific anomalous anticyclone during El Niño. Part I: maintenance mechanisms. J Clim 30:9621-9635

Wu B, Zhou T, Li T (2017b) Atmospheric dynamic and thermodynamic processes driving the western North Pacific anomalous anticyclone during El Niño. Part II: formation processes. J Clim 30:9637-9650

Yuan X, Liu X (2013) Onset-withdrawal dates of autumn persistent rains over West China and the associated autumn to winter evolution of the atmospheric circulation. Acta Meteor Sin 71(5):913-924
Zhang R, Sumi A, Kimoto M (1999) A diagnostic study of the impact of El Niño on the precipitation in China. Adv Atmos Sci 16:229-241

Zhang C, Wang Z, Zhou B, Li Y, Tang H, Xiang B (2018) Trends in autumn rain of West China from 1961 to 2014. Theor Appl Climatol. https://doi.org/10.1007/s00704-017-2361-9

Zheng R, Liu J, Ma Z (2018) Impacts of the summertime warm pool in the West Pacific on Huaxi autumn rain and its possible physical mechanism. Acta Meteor Sin 76:714-725 